\title{
Glucose-regulated protein 78 demonstrates antiviral effects but is more suitable for hepatocellular carcinoma prevention in hepatitis B
}

Nai Q. Zheng ${ }^{1+}$, Zi H. Zheng ${ }^{2+}$, Hai X. Xu ${ }^{1}$, Ming X. Huang ${ }^{3}$ and Xiao M. Peng ${ }^{3^{*}}$

\begin{abstract}
Background: Hepatitis B virus (HBV) is the leading cause of liver cirrhosis and hepatocellular carcinoma in Asia and Africa. Existing antivirals cannot cure HBV or eliminate risk of hepatocellular carcinoma. Glucose-regulated protein 78 (GRP78) can inhibit HBV replication, but promote virion secretion and hepatocellular cancer cell invasion. For these reasons, the overall effect of GRP78 on HBV production and whether to utilize the HBV replication-inhibitory effect of GRP78 up-regulation or the hepatocellular cancer cell invasion-inhibitory effect of its down-regulation were further investigated in order to improve the efficacy of current antiviral therapy.

Methods: GRP78 regulations in HepG2.2.15 cells were conducted by transfections of expressing vector and small interfering RNA, respectively. The changes in HBV replication, hepatitis B e antigen (HBeAg) synthesis and hepatoma cell motility were monitored.

Results: GRP78 overall decreased HBV production due to its HBV replication-inhibitory effect time-dependently overwhelming virion secretion-promoting effect in HepG2.2.15 cells. Unlike the parental cells (HepG2), HepG2.2.15 cells demonstrated decreased expressions of the major genes in the interferon- $\beta 1$-dependent pathway. Moreover, the expressions of these genes were not affected by GRP78 regulations. However, GRP78 was found to inhibit HBeAg secretion and to increase the retro-transportation of capsid assembly-interfering HBeAg precursor from the endoplasmic reticulum into the cytosol where new viral nucleocapsids formed. Furthermore, GRP78 overexpression promoted wound healing process (the motility) of HepG2.2.15 cells. In contrast, GRP78 knockdown enhanced HBV replication and HBeAg secretion, but they were abolished by entecavir and furin inhibitor, respectively.

Conclusions: GRP78 mainly demonstrates anti-HBV effects, reducing HBV production and HBeAg secretion. With due regard to the hepatocellular cancer invasion risk of the overexpression and the rectifiability of the unpleasant effects of the knockdown, GRP78 down-regulation may be more suitable to serve as an additive strategy to cover the hepatocellular cancer prevention shortage of current antiviral therapy in the future.
\end{abstract}

Keywords: Hepatitis B virus, Chronic hepatitis B, Hepatocellular carcinoma, Antiviral therapy, Glucose-regulated protein 78

\footnotetext{
* Correspondence: xiaomoupeng@hotmail.com

${ }^{\dagger}$ Equal contributors

${ }^{3}$ Center of Infectious Diseases, the Fifth Affiliated Hospital, Sun Yat-Sen

University, 52 Meihua East Road, Zhuhai 519000, Guangdong, China

Full list of author information is available at the end of the article
} 


\section{Background}

Hepatitis B virus (HBV) is the leading cause of liverrelated deaths in Asia and Africa although there are effective vaccines for decades. Persistent existence of HBV replication is an independent risk factor for liver cirrhosis and hepatocellular carcinoma (HCC) [1, 2]. Antiviral therapy based on current options, recombinant interferon (IFN)- $\alpha$ and nucleotide/nucleoside analogs, has markedly reduced the incidence of liver cirrhosis and HCC [3, 4]. However, it hardly eliminates HBV infection and the suppression of viral replication below the limit of detection does not completely prevent HCC development although liver fibrosis can be stopped $[4,5]$. For examples, during nucleoside analog lamivudine treatment, the cumulative HCC rate at 5 years is $3 \%$ in patients with chronic hepatitis $\mathrm{B}(\mathrm{CHB})$ and up to $30 \%$ in those with liver cirrhosis, and even for the more effective and lower resistant entecavir (ETV), five year-treatment only reduces $\mathrm{HCC}$ risk from 13.7 to $3.7 \%$ in patients with $\mathrm{CHB}$ or advanced liver fibrosis [6,7]. As for the cumulative HCC rates at 10 years, the situation is even worse. No matter ETV or lamivudine is used, such rates are up to 29.6 and $53.4 \%$ in patients with $\mathrm{CHB}$ and liver cirrhosis, respectively [8]. Thus, it remains imperative to search for new therapeutic targets against HBV infection or HCC development.

HBV is a hepatotropic enveloped virus with $3.2-\mathrm{kb}$ partially double-stranded circular viral genome. The viral genome is packaged inside the capsid that is assembled by viral core protein (hepatitis B core antigen, $\mathrm{HBcAg}$ ) to generate nucleocapsid in cytosol. The viral envelope mainly consists of small-surface protein (hepatitis B surface antigen, HBsAg). Some small surface protein has additional extensions of pre-S2 (middle surface protein) or pre-S1 and pre-S2 (large surface protein) in $\mathrm{N}$-terminus. These proteins are cotranslationally integrated into the endoplasmic reticulum (ER) membrane. While penetrates into the ER lumen, the viral nucleocapsid is packaged with these trans-membrane proteins to generate mature virions [9]. During the life cycle, HBV also synthesized a secretory core protein that finally matures into hepatitis $\mathrm{B}$ e antigen (HBeAg). During synthesis, the nascent peptide chain is directed to the ER by a signal sequence, and develops into $\mathrm{HBeAg}$ precursor after the signal sequence is removed. $\mathrm{HBeAg}$ precursor is further digested by furin in the Golgi apparatus to generate mature $\mathrm{HBeAg}[10,11]$. $\mathrm{HBeAg}$ precursor detained in the ER or undigested by furin is retro-transported to cytosol or expresses on the surface of hepatocytes [12, 13]. HBeAg released into bloodstream serves as an immunotolerance inducer [14-16]. In contrast, $\mathrm{HBeAg}$ precursor on the cell surface has chance to initiate antiviral immunity and in cytosol can inhibit HBV replication via formation of capsidationincompetent capsids with $\mathrm{HBcAg}$ [17-19].
Glucose-regulated protein 78 (GRP78/BiP) constitutively expresses in the ER. It is involved in the major functions of the ER by translocating newly synthesized polypeptides across the ER membrane, facilitating the folding and secretion of proteins, targeting misfolded or unnecessary proteins for ER-associated protein degradation, and serving as the ER stress sensor to release cells from the stress conditions [20,21]. With regard to HBV infection, GRP78 is at least involved in four important processes, viral replication, viral secretion, $\mathrm{HBeAg}$ secretion and HBV-related hepatocellular carcinogenesis. GRP78 has been reported to inhibit HBV replication by facilitating HBV transcript degradation via activation of IFN- $\beta 1$ 2 ',5' -oligoadenylate synthetase-RNase L pathway [22], to promote virion secretion via guiding posttranslational ER translocation of the HBV large envelope protein [23, 24], to enhance the retro-transportation of $\mathrm{HBeAg}$ precursor from the ER into cytosol [12], which may affect $\mathrm{HBeAg}$ secretion, and to facilitate the migration and invasion of HCC via reduction of ER stress-induced apoptosis, expression on cell-surface or conferring drug resistance [25-28]. The effect of HBV replication inhibition suggest that GRP78 up-regulation is of therapeutic potential for chronic HBV infection, but the rest effects on promoting virion secretion and HCC invasion argue against the above potential. Those contradictory effects let us not know the overall effect of GRP78 on HBV production and how to make a choice to utilize the anti-HBV effect of up-regulation or the cancer-preventing effect of down-regulation of GRP78 in the future.

In this study, the overall effect of GRP78 was found to decrease HBV production due to its HBV replicationinhibitory effect time-dependently overwhelming virion secretion-promoting effect in HepG2.2.15 cells. It also inhibited $\mathrm{HBeAg}$ secretion via enhancing the retrotransportation of $\mathrm{HBeAg}$ precursor. However, GRP78 overexpression significantly increased the motility of HepG2.2.15 cells. In contrast, GRP78 knockdown accumulated intracellular HBV DNA and increased $\mathrm{HBeAg}$ secretion, but fortunately abrogated by co-treatment with ETV and furin inhibitor hex-D-arginine (D6R), respectively. These findings have clarified the overall effect of GRP78 on HBV replication and have many implications for strategy searches in order to cover the HCC prevention shortage of current antiviral therapy in the future.

\section{Results}

GRP78 overwhelms its viral secretion-promoting effect to suppress HBV production in HepG2.2.15 cells

GRP78 has been reported to promote the secretion of HBV particles in HepG2.2.15 cells, but to act as an intracellular anti-HBV factor in HepAD38, a cell line with Tetoff promoter to control its HBV production [22-24]. Though both reports used siRNA to down-regulate 
GRP78, the decrease and increase in supernatant HBV particles were observed, respectively. This discordance may result from the difference in cell models. Compared with HepAD38 cells, HepG2.2.15 cells produce HBV particles in a continuous manner, which better mimics the persistent infection state of patients. For this reason, HepG2.2.15 cells were used in this study to clarify the overall effect of GRP78 on HBV production. GRP78 was successfully up-regulated and down-regulated by transfections of the recombinant expression plasmid and the siRNA of GRP78, respectively (Fig. 1a). GRP78 overexpression reduced supernatant and intracellular coreassociated HBV DNA and GRP78 knockdown showed the opposite effect (Fig. 1b and c). GRP78 was regularly detected as two bands, perhaps due to splice variation.

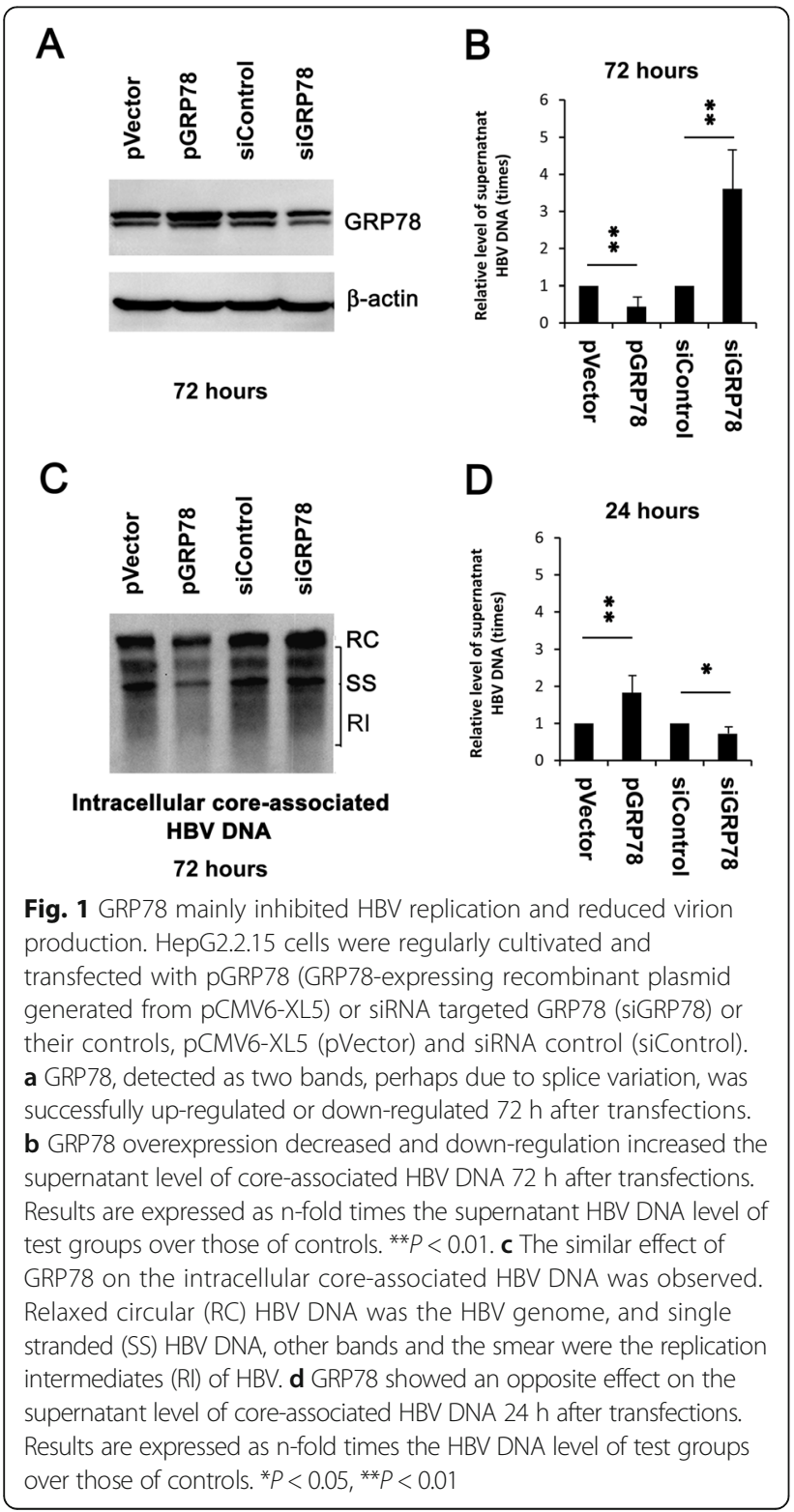

Though the same cell model was used, the effect of GRP78 here was opposite to that reported in the published literature [24], which may result from the uses of different observation time, $72 \mathrm{~h}$ in this study and $24 \mathrm{~h}$ in literature. To test this possibility, supernatant coreassociated HBV DNA was detected $24 \mathrm{~h}$ after transfections (Fig. 1d). As result, GRP78 indeed moderately increases the supernatant level of $\mathrm{HBV}$ particles. Furthermore, GRP78 was found to inhibit HBV production slightly $48 \mathrm{~h}$ and significantly $96 \mathrm{~h}$ after transfections. The above results suggest that the HBV replication-inhibiting effect of GRP78 time-dependently overwhelmed its viral secretionpromoting effect and that GRP78 mainly inhibits HBV production in patients with persistent infection.

\section{GRP78 may not inhibit HBV replication by the IFN- $\beta$ 1- dependent pathway in HepG2.2.15 cells}

GRP78 reduced HBV production by inhibiting viral DNA replication (Fig. 1). However, the underlying mechanism in HepG2.2.15 cells is unclear yet. Based on the findings in HepG2 cells (parent cells of HepG2.2.15), GRP78 has been reported to inhibit HBV replication through the activation of the IFN- $\beta 1-2^{\prime}, 5^{\prime}$-oligoadenylate synthetaseRNase L pathway [22]. Here, we wonder whether GRP78 similarly inhibits HBV replication in HepG2.2.15 cells. Unexpectedly, GRP78 overexpression or knockdown did not significantly affect the mRNA levels of IFN- $\beta 1$ and RNase L genes (Fig. 2a) or the protein level of IFN- $\beta 1$ (Fig. 2b) in HepG2.2.15 cells. To clarify the reasons behind the deviation in HepG2.2.15 cells, we further compared the expression levels of those genes of interest between these two cell lines. As results, the mRNA levels of IFN- $\beta 1$ and RNase L genes in HepG2.2.15 cells were only about $1 / 10$ and $1 / 100$ of those in HepG2 cells, respectively (Fig. 2c). Similarly, the protein level of IFN- $\beta 1$ in HepG2.2.15 cells was much lower than that in HepG2 cells (Fig. 2d). These results ascertain that the IFN- $\beta 1$ dependent pathway has been blocked and GRP78 does not inhibit HBV replication by this pathway in HepG2.2.15 cells.

GRP78 decreases HBeAg secretion and increases the retrotransportation of $\mathrm{HBeAg}$ precursor from the ER to cytosol As an ER-resident chaperon protein, GRP78 is reported to specifically co-immunoprecipitate $\mathrm{HBeAg}$ precursor and assist its retro-transportation from the ER to the cytosol [12]. In addition, $\mathrm{HBeAg}$ precursor in the cytosol is of potential to inhibit HBV replication through formation of encapsidation-incompetent hybrid capsids with core protein [18, 19]. Therefore, GRP78 may inhibit HBV replication by its promoting effect on the cytosolic retro-transportation of $\mathrm{HBeAg}$ precursor. In addition, the enhanced retro-transportation of HBeAg precursor 


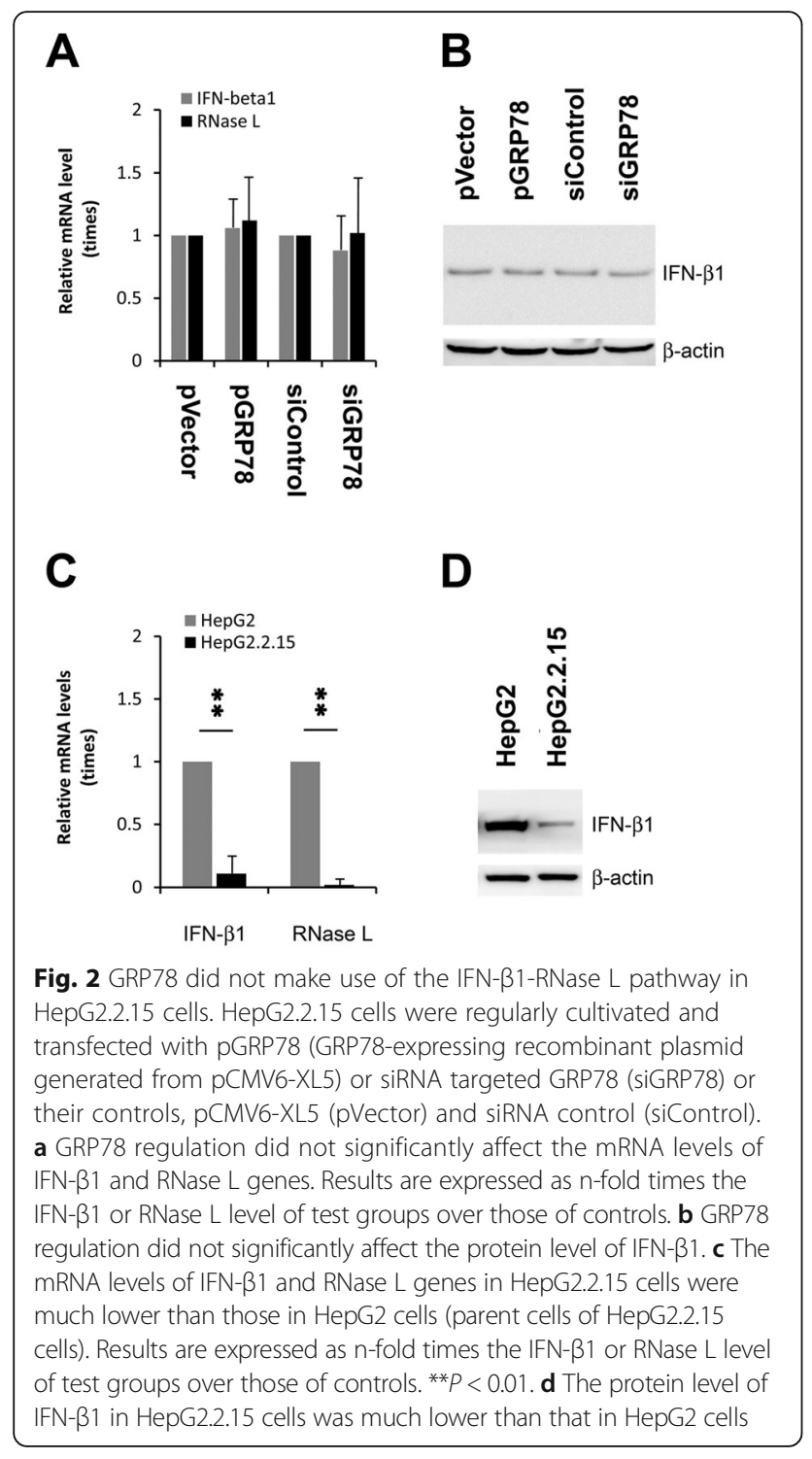

may reduces $\mathrm{HBeAg}$ synthesis, which is meaningful for HBeAg seroconversion in clinical practice. Indeed, GRP78 overexpression resulted in the increase in cytosolic $\mathrm{HBeAg}$ precursor and the decreases in $\mathrm{HBeAg}$ secretion (Fig. 3a and b). In contrast, GRP78 knockdown showed the opposite effects. Other bands that varied as P22 or HBeAg are core-related peptides with modification or degradation in different degree [29].

These results further ascertain the anti-HBV effects of GRP78 and suggest that GRP78 inhibits HBV replication by promoting the retro-transportation of $\mathrm{HBeAg}$ precursor from the ER to the cytosol in HepG2.2.15 cells.

\section{GRP78 up-regulation promotes wound healing in HepG2.2.15 cells}

The above results indicate that GRP78 inhibits both $\mathrm{HBV}$ production and $\mathrm{HBeAg}$ secretion, correlating with

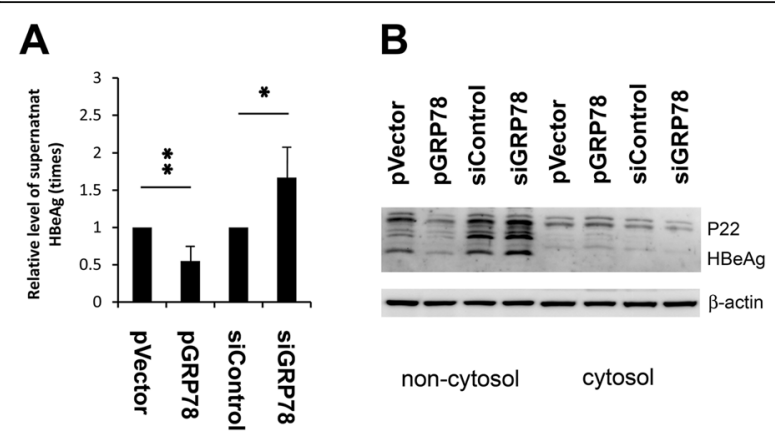

Fig. 3 GRP78 promoted the cytosolic retro-transportation of P22 in HepG2.2.15 cells. HepG2.2.15 cells were regularly cultivated and transfected with pGRP78 (GRP78-expressing recombinant plasmid generated from pCMV6-XL5) or siRNA targeted GRP78 (siGRP78) or their controls, pCMV6-XL5 (pVector) and siRNA control (siControl). a GRP78 significantly inhibited HBeAg secretion. Results are expressed as $n$-fold times the supernatant HBeAg level of test groups over those of controls. ${ }^{*} P<0.05,{ }^{*} P<0.01$. b GRP78 promoted the retrotransportation of HBeAg precursor (P22) from ER to cytosol. Total cytosolic proteins (cytosol) and non-cytosolic proteins (non-cytosol) were separately extracted. The rest bands that varied as P22 or $\mathrm{HBeAg}$ are core-related peptides with modification or degradation in different degree

virological and serological responses in clinical practice and suggesting that GRP78 up-regulation as anti-HBV strategy is somewhat better than current viral polymerase-selective inhibitors. However, increasing data imply that GRP78 is involved in the invasion and migration of HCC and other cancers $[25,26]$. Since above results show that HepG2.2.15 was unlike other hepatoma cell line in which HBV is inhibited through the IFN- $\beta 1$-dependent pathway, the cell mobility effects of GRP78 on this cell line was further studied. As results, GRP78 overexpression was found to promote wound healing $48 \mathrm{~h}$ after transfection (Fig. $4 \mathrm{a}$ and b). This promotion

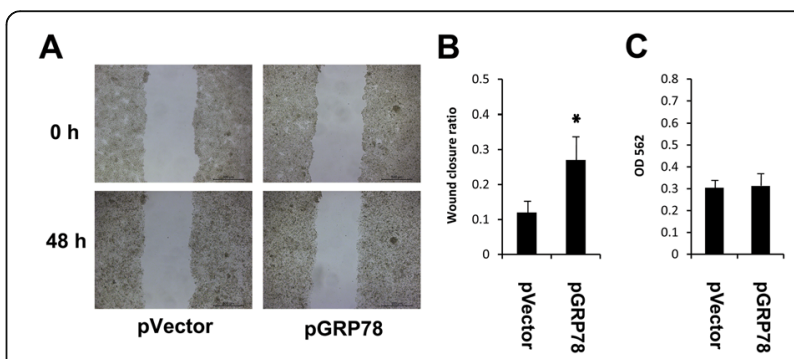

Fig. 4 GRP78 overexpression promoted wound healing in HepG2.2.15 cells. HepG2.2.15 cells were regularly cultivated and transfected with pGRP78 (GRP78-expressing recombinant plasmid generated from pCMV6-XL5) or empty vector, pCMV6-XL5 (pVector). a After transfection, confluent cells were wounded by sterile pipettes and the wound statuses were photographed at the beginning and $48 \mathrm{~h}$ after wounded. b Cells with GRP78 overexpression had a significantly higher wound closure ratio. ${ }^{*} P<0.05$. c Cell proliferation was examined using MTT analysis. The proliferation statuses of those cells with and without GRP78 overexpression were identical $48 \mathrm{~h}$ after wounded 
resulted from the enhanced cell mobility rather than the possible effect of GRP78 on cell proliferation since the proliferation statuses of those cells with and without GRP78 overexpression were similar (Fig. 4c).

\section{GRP78 knockdown enhances HBV replication and HBeAg} secretion, but which are abolished by ETV and D6R

$\mathrm{HCC}$ is a fatal complication of chronic HBV infection and its prophylaxis of current antiviral options is far from satisfaction [4-8]. Based on its characteristics to inhibit HBV secretion and cancer invasion, GRP78 down-regulation may be a promising supplement for current antiviral options. However, GRP78 down-regulation significantly increased HBV replication and HBeAg secretion (Figs. 1 and 3). Our previous study has shown that ETV, a broadly accepted antiviral drug in clinical practice, combined with D6R, a furin inhibitor that moderately inhibits HBeAg secretion but is unlike the other common furin inhibitor to enhance HBV replication [13], inhibits HBV replication and $\mathrm{HBeAg}$ secretion simultaneously [30]. For these reasons, we here examined whether ETV and D6R coped with those unpleasant effects. Fortunately, ETV completely abolished the HBV replication-enhancing effect of GRP78 knockdown though its own effect was moderately reduced (Fig. 5a and b). Similarly, D6R completely abolished the HBeAg secretion-enhancing effect (Fig. 5c).
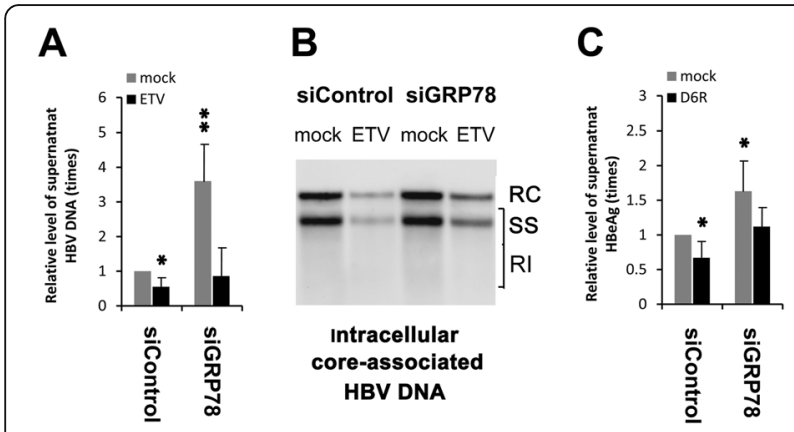

Fig. 5 ETV and D6R abolished the enhancing effects of GRP78 downregulation on $\mathrm{HBV}$ replication and $\mathrm{HBeAg}$ secretion. HepG2.2.15 cells were regularly cultivated, transfected with siRNA targeted GRP78 (siGRP78) or its control (siControl) and treated with or without ETV ( $20 \mathrm{nmol} / \mathrm{L}$ ) or furin inhibitor II (D6R, $100 \mu \mathrm{mol} / \mathrm{L})$. a ETV abolished the enhancing effect of GRP78 down-regulation on supernatant coreassociated HBV DNA. Results are expressed as n-fold times the supernatant HBV DNA level of test groups over those of controls. ${ }^{*} P<0.05$, ${ }^{*} P<0.01$. b. ETV abolished the enhancing effect of GRP78 downregulation on intracellular core-associated HBV DNA. Relaxed circular (RC) HBV DNA was the HBV genome, and single stranded (SS) HBV DNA, other bands and the smear were the replication intermediates (RI) of HBV. c Furin inhibitor abolished the enhancing effect of GRP78 down-regulation on $\mathrm{HBeAg}$ secretion. Results are expressed as n-fold times the supernatant $\mathrm{HBeAg}$ level of test groups over those of controls. ${ }^{*} P<0.05$

\section{Discussion}

GRP78 has contradictory effects on HBV life cycle, inhibiting HBV replication and promoting HBV secretion [22-24]. In this study, the overall effect of GRP78 was found to decrease HBV production due to its HBV replication-inhibitory effect time-dependently overwhelming virion secretion-promoting effect in HepG2.2.15 cells, probably due to HBV replication is an upstream event in viral life cycle, implying that GRP78 mainly inhibits HBV replication in patients with persistent infection. Indeed, GRP78 overexpression showed anti-HBV effects, decreases in HBV DNA replication and HBeAg secretion, implying to be favorable for common antiviral goals, undetectable HBV DNA and HBeAg seroconversion in clinical practice. However, GRP78 overexpression increased the mobility of HepG2.2.15 cells based on wound healing tests, which implies the involvement in HCC tumorigenesis and dims the clinical prospect of GRP78 upregulation. It also suggests that GRP78 knockdown may be favorable for HCC prevention. However, GRP78 knockdown was found to increase HBV replication and HBeAg secretion. Therefore, the above findings imply that GRP78 down-regulation is suitable to serve as a supplementary strategy to improve the HCC prevention efficacy of current antiviral options once the enhancements of HBV replication and $\mathrm{HBeAg}$ secretion are effectively blocked.

The mechanism for GRP78 to inhibit HBV replication as well as the secretions of HBsAg and HBeAg is not completely clarified. GRP78 overexpression up-regulates the expressions of IFN- $\beta 1$, OAS1, OAS2 and RNase L genes and IFN- $\beta 1$ treatment in return up-regulates the expression of GRP78 in HepG2 cells, implying that the anti-HBV mechanism of GRP78 correlates with the IFN 31 -dependent pathway [22]. However, in this study, we found that HepG2.2.15 cells expressed much less constitutive IFN- $\beta 1$ and RNase $\mathrm{L}$ when compared with HepG2 cells, which is in concordance with the report of other scientists [31, 32]. In addition, GRP78 overexpression or knockdown did not significantly affect the expressions of both mentioned genes. On the other hand, GRP78 was found to promote the retro-transportation of $\mathrm{HBeAg}$ precursor from the ER to the cytosol in HepG2.2.15 cell. It is well-documented that cytosolic $\mathrm{HBeAg}$ precursor can inhibit HBV replication by formation of HBV encapsidationincompetent capsids $[18,19]$. Therefore, these above results ascertain that the IFN- $\beta 1$-dependent pathway has been blocked in HepG2.2.15 cell and GRP78 inhibits HBV replication by promoting retro-transportation of $\mathrm{HBeAg}$ precursor from the ER to the cytosol. To restore the vigor of the IFN- $\beta 1$-dependent pathway may be a new strategy to treat $\mathrm{CHB}$ in the future.

Immune tolerance is a major factor underlying the maintenance of chronic HBV infection. HBeAg as an immunotolerance inducer plays key roles in the 
maintenance of immune tolerance as shown by the facts that $\mathrm{HBeAg}$-defective variants rarely cause a de novo chronic infection and that $\mathrm{HBeAg}$ modulates host immune responses to $\mathrm{HBcAg}$ [14-16]. In this study, GRP78 was found to inhibit HBeAg secretion via enhancement of the retro-transportation of $\mathrm{HBeAg}$ precursor, which is meaningful for HBeAg seroconversion, an important treatment endpoint, in clinical practice.

It is well documented that GRP78 facilitates invasions of HCC and other cancers [25-27]. Perhaps due to the persistent existence of HBV, HepG2.2.15 cells was unlike other hepatoma cell line in which HBV is inhibited through the IFN- $\beta 1$-dependent pathway. However, based on wound healing tests, the effect of GRP78 on the mobility of HepG2.2.15 cells was similar to that of HBV-free cell lines. In addition, GRP78 usually highly expresses in HCC tissues, and the expression level is positively correlates with portal and intra-hepatic invasions [33, 34]. The HCC-contributing mechanisms of GRP78 include alleviating the ER stress, mediating by loss of the tumor suppressor PTEN and enhancing the activation and activity of FAK [35-37]. Thus, it is ascertained that GRP78 is substantially involved in HCC tumorigenesis. Because HCC is a fatal complication of chronic HBV infection, the possibility of GRP78 up-regulation as an anti-HBV strategy seems to be dismissed unless GRP78 up-regulation can lead to the rapid elimination of chronic HBV infection in early stage. Unfortunately, it is well known that the elimination of chronic HBV infection is an ambitious expectation currently.

The HCC prevention efficacy of current antiviral options is urged to improve, especially for patients with liver cirrhosis [4-8]. The on-treatment cumulative HCC rate at 5 years is about $3 \%$ in patients with $\mathrm{CHB}$ and up to $30 \%$ in those with cirrhosis. The on-treatment cumulative $\mathrm{HCC}$ rate at 10 years is about $30 \%$ in patients with $\mathrm{CHB}$ and up to $50 \%$ in those with cirrhosis. In view of the effects of GRP78 on HCC, GRP78 down-regulation may be a potentially supplementary measure to improve the HCC prevention efficacy of current antiviral therapy. Indeed, GRP78 knockdown may decrease the invasion capability, reduce the risk of resistance to sorafenib and enhance the adenosine-induced apoptosis [27, 38, 39]. However, some articles report the opposite effect. GRP78 down-regulation enhances migration ability in some cell lines of HCC, perhaps due to their unique pattern of GRP78 expression [40, 41]. In addition, GRP78 down-regulation enhanced HBV replication and HBeAg secretion though these unpleased effects were abrogated by ETV and furin inhibitor, respectively. Therefore, GRP78 as a therapeutic target is of potential, but has substantial limitations, which urges for more intensive studies in the future.

\section{Conclusions}

Although it mainly demonstrates anti-HBV effects, GRP78 is not a suitable anti-HBV target due to its potential risk of HCC invasion. Fortunately, GRP78 downregulation is of potential to be an additive strategy to cover the HCC prevention shortage of current antiviral therapy.

\section{Methods}

Plasmid constructs and siRNA synthesis

GRP78-expressing recombinant plasmid, pGRP78, and its original plasmid pCMV6-XL5 (named as pVector in this study) were purchased from OriGene Technologies, Rockville, MD, USA. The small interfering RNA (siRNA) against GRP78, siGRP78, (5' -CCAAG AUGCU GACAU UGAA dTdT-3') and the negative control siRNA against the severe acute respiratory syndrome coronavirus, siControl, (5' -GCACU UGUCU ACCUU GAUG dTdT-3') were synthesized by RiboBio Corporation, Guangzhou, China.

\section{Cell culture and transfections}

HepG2 and HepG2.2.15 cells were grown in Dulbecco's modified Eagle's medium with $10 \%$ fetal bovine serum. For HepG2.2.15 cells, the medium was supplemented with $380 \mu \mathrm{g} / \mathrm{mL}$ geneticin. HepG2.2.15 cells were transfected with $1.6 \mu \mathrm{g} /$ well pGRP78 or pVector and $200 \mathrm{nmol} / \mathrm{L}$ siGRP78 or siControl, respectively. All transfections were performed in 12-well plates suing Lipofectamine 2000 (Invitrogen Corporation, Shanghai, China) according to the manufacturer's instructions. To abolish the effects of GRP78 down-regulation on HBV replication or HBeAg secretion, cells were treated with $20 \mathrm{nmol} / \mathrm{L}$ ETV (SigmaAldrich Corporation, St. Louis, MO, USA) or $100 \mu \mathrm{mol} / \mathrm{L}$ D6R (EMD Biosciences, La Jolla, CA, USA), respectively. To evaluate HBV replication and GRP78 expression, cells were harvested $72 \mathrm{~h}$ after transfection unless otherwise indicated.

Detections of GRP78, IFN- $\beta 1$ and intracellular HBV antigens For the detection of GRP78 and IFN- $\beta 1$, total cellular proteins were prepared by lysing the cells on ice for


$150 \mathrm{mmol} / \mathrm{L} \mathrm{NaCl}, 1 \% \mathrm{NP}-40,1 \% \mathrm{SDS}, 1 \mathrm{mmol} / \mathrm{L}$ phenylmethylsulfonyl fluoride, $10 \mathrm{mg} / \mathrm{L}$ aprotinin, $10 \mathrm{mg} / \mathrm{L}$ leupeptin). For the detections of intercellular $\mathrm{HBcAg}$, $\mathrm{HBeAg}$ and $\mathrm{HBeAg}$ precursor the cytosolic and noncytosolic cellular proteins were separately extracted as reported [12]. Briefly, after cell membrane was cautiously broken on ice by a digitonin buffer $(50 \mathrm{mmol} / \mathrm{L}$ Tris, $\mathrm{pH} 8,150 \mathrm{mmol} / \mathrm{L} \mathrm{NaCl}, 22.5 \mathrm{mg} / \mathrm{L}$ digitonin, $0.5 \mathrm{mmol} / \mathrm{L}$ phenylmethylsulfonyl fluoride, $1 \mathrm{mg} / \mathrm{L}$ aprotinin, $1 \mathrm{mg} / \mathrm{L}$ leupeptin), the cytosolic fraction of cell lysates including soluble cellular proteins and the non-cytosolic fraction 
including the cellular proteins of remaining cell debris (nucleus, endoplasmic reticulum and Golgi complex) were extracted independently. Sampling was normalized to total cellular, cytosolic or non-cytosolic proteins. The total and sorted cellular proteins were separated and transferred onto polyvinylidene fluoride membranes (Millipore Corporation, Billerica, MA, USA) using standard techniques. Immunoblot analysis was performed using polyclonal antibodies to human GRP78 (Novus Biologicals, Littleton, CO, USA), IFN- $\beta 1$ (Novus Biologicals,) or $\mathrm{HBcAg}$ (DAKO, Carpinteria, CA, USA) and enhanced chemiluminescence reagent (Invitrogen Corporation, Shanghai, China).

\section{Detections of supernatant and intracellular core- associated HBV DNA}

The isolations of supernatant and intracellular core particles were performed as reported [42]. The coreassociated HBV DNA was extracted using phenolchloroform after digested with $60 \mathrm{mg} / \mathrm{L}$ of proteinase $\mathrm{K}$ at $55{ }^{\circ} \mathrm{C}$ for $1 \mathrm{~h}$. The supernatant core-associated HBV DNA was quantitatively examined using realtime fluorescent polymerase chain reaction (PCR) (Taan Gene Company, Guangzhou, china). The intracellular core-associated HBV DNA was detected using Southern blot analysis. Sampling was balanced based on the protein level in cell lysate. The isolated DNA was separated and transferred onto nylon membranes (Roche Applied Science, Indianapolis, IN, USA). After hybridized with digoxigenin-labeled DNA probes, all membranes were incubated with horseradish peroxidaselabeled anti-digoxigenin antibody (Roche Applied Science), and developed with an enhanced chemiluminescence reagent (Invitrogen Corporation).

\section{Quantitative detections of the mRNA levels of IFN- $\beta 1$ and RNase $\mathrm{L}$ genes}

The cellular total RNA was extracted using TRIzol (Invitrogen Corporation) according to the manufacturer's instructions. After DNase I (Ambion, Austin, TX, USA) treatment and quantification by photospectrometry, RNA purity was assessed by electrophoresis on $1 \%$ agarose gels, and then $1 \mathrm{ng}$ of total RNA was reverse transcribed in a $20 \mu \mathrm{l}$ reaction (Promega, Madison, WI, USA) according to the kit manufacturer's protocol. The relative mRNA levels of IFN- $\beta 1$, RNase L and glyceraldehyde-3-phosphate dehydrogenase (GAPDH, housekeeping control) were quantified using SYBR Green Real-Time PCR Kits (Takana Bio, Otsu, Japan). The primers were as follows: IFN- $\beta 1$ (211 bp), forward 5' - GACCA ACAAG TGTCT CCTCC AAA - 3 ', reverse 5' - GAACT GCTGC AGCTG CTTAA TC -3'; RNase L (141 bp), forward 5' - TTGAG GCGAA AGACA AAGGA G -3', reverse 5' - GTCAC AGGCG TTTAC ATCTG C -3'; and GAPDH (138 bp), forward 5' -GCACC GTGAA GGCTG AGAAC-3', reverse
5'-TGGTG AAGAC GCCAG TGGA-3'. The reaction was performed using $2 \mu \mathrm{l}$ of reverse transcription product for each sample, and three runs of real-time PCR were performed for every sample. Amplification was conducted at $95^{\circ} \mathrm{C}$ for $5 \mathrm{~s}$, and an annealing temperature of $60{ }^{\circ} \mathrm{C}$ for $31 \mathrm{~s}$ over 40 cycles. At the end of each program, melting curve analysis was carried out. Data for IFN- $\beta 1$ and RNase $\mathrm{L}$ were normalized using expression of the housekeeping gene GAPDH in order to ensure comparability.

\section{Detection of supernatant $\mathrm{HBeAg}$}

$\mathrm{HBeAg}$ in media was quantified using commercial kits of chemiluminescence immunoassay (USCNK Life Science Incorporation, Wuhan, China).

\section{Wound healing and cell proliferation analyses}

Cell monolayer with or without GRP78 overexpression was carefully wounded by sterile pipette. After removing the debris by 3 times of washes with PBS, the monolayer was cultured in Dulbecco's modified Eagle's medium containing $0.5 \%$ fetal bovine serum for $48 \mathrm{~h}$. Photographs (by microscope, $\times 100$ ) were taken immediately after wound incision and at the time point of $48 \mathrm{~h}$. Would closure ratio $=$ (initial width - later width $) /$ initial width. Ten would closure ratios at different locations were calculated for each monolayer. For cell proliferation assay, $500 \mu \mathrm{l}$ sterilized 3-(4,5-dimethyl-2-thiazolyl)2,5-diphenyl-2-H-tetrazolium bromide (MTT) solution $(0.5 \mathrm{mg} / \mathrm{ml})$ were added into each well and the cells were incubated for $4 \mathrm{~h}$ in normal culture condition. The absorbance at $562 \mathrm{~nm}$ was measured using microplate reader after the crystallization was dissolved by $500 \mu \mathrm{l}$ dimethylsulfoxide.

\section{Statistical analysis}

The differences in supernatant HBV DNA and HBeAg, the mRNA levels of IFN- $\beta 1$ and RNase L, wound closure ratios and cell proliferations were analyzed using the Student's $t$-test based on the data from three independent experiments that were normally consisted of three independent tests each. A $P<0.05$ was considered statistically significant. All statistical analyses were conducted using SPSS software (version 11; SPSS Incorporation, Chicago, IL, USA).

\footnotetext{
Abbreviations

CHB: Chronic hepatitis B; D6R: Hex-D-arginine; ER: Endoplasmic reticulum; ETV: Entecavir; GAPDH: Glyceraldehyde-3-phosphate dehydrogenase; GRP78: Glucose-regulated protein; HBCAg: Hepatitis B core antigen; HBeAg: Hepatitis B e antigen; HBsAg: Hepatitis B surface antigen; HBV: Hepatitis B virus; HCC: Hepatocellular carcinoma; IFN: Interferon; MTT: 3-(4,5-dimethyl-2-thiazolyl)-2,5-diphenyl-2-H-tetrazolium bromide; PCR: Polymerase chain reaction; siRNA: Small interfering RNA
}

\section{Acknowledgements}

We thank the clerks in Liver Disease Key Laboratory of Guangdong Province, Guangzhou, China, for technical assistance. 


\section{Funding}

This work was supported by grants from the National Nature Scientific Foundation (No. 81071366) and the Scientific and Technological Bureau of Guangzhou, Guangdong Province (No. 201508020059), China. The funding bodies does not participate in the design of the study and collection, analysis, and interpretation of data and in writing the manuscript.

\section{Availability of data and materials}

$$
\text { Not applicable. }
$$

\section{Authors' contributions}

Conception of the idea and design of the experiments are due to XMP. The manuscript was written and drafted by XMP, NQZ and ZHZ. Cell cultivation, Western Blot, Southern Blot and APCR analyses were conducted by NQZ, $\mathrm{ZHZ}, \mathrm{HXX}$ and $\mathrm{MXH}$. All authors read and approved the final manuscript.

\section{Competing interests}

The authors declare that they have no competing interests.

\section{Consent for publication}

Not applicable.

\section{Ethics approval and consent to participate}

Not applicable.

\section{Publisher's Note}

Springer Nature remains neutral with regard to jurisdictional claims in published maps and institutional affiliations.

\section{Author details}

${ }^{1}$ Department of Infectious Diseases, the Third Affiliated Hospital, Sun Yat-Sen University, Guangzhou, China. ${ }^{2}$ Jinan University Clinic, the First Affiliated Hospital of Jinan University, Guangzhou, China. ${ }^{3}$ Center of Infectious Diseases, the Fifth Affiliated Hospital, Sun Yat-Sen University, 52 Meihua East Road, Zhuhai 519000, Guangdong, China.

\section{Received: 22 September 2016 Accepted: 6 April 2017}

\section{Published online: 13 April 2017}

\section{References}

1. Ganem D, Prince AM. Hepatitis B virus infection-natural history and clinical consequences. N Engl J Med. 2004;350(11):1118-29.

2. Liaw YF. Natural history of chronic hepatitis B virus infection and long-term outcome under treatment. Liver Int. 2009;29 Suppl 1:100-7.

3. Lok AS, McMahon BJ, Brown Jr RS, Wong JB, Ahmed AT, Farah W, Almasri J, Alahdab F, Benkhadra K, Mouchli MA, Singh S, Mohamed EA, Abu Dabrh AM, Prokop LJ, Wang Z, Murad MH, Mohammed K. Antiviral therapy for chronic hepatitis B viral infection in adults: a systematic review and metaanalysis. Hepatology. 2016;63(1):284-306.

4. Orito E, Hasebe C, Kurosaki M, Osaki Y, Joko K, Watanabe H, Kimura H, Nishijima N, Kusakabe A, Izumi N. Risk of hepatocellular carcinoma in cirrhotic hepatitis B virus patients during nucleoside/nucleotide analog therapy. Hepatol Res. 2015;45(8):872-9.

5. Papatheodoridis GV, Manolakopoulos S, Touloumi G, Nikolopoulou G, Raptopoulou-Gigi M, Gogos C, Vafiadis-Zouboulis I, Karamanolis D, Chouta A, Ilias A, Drakoulis C, Mimidis K, Ketikoglou I, Manesis E, Mela M, Hatzis G, Dalekos GN, HepNet.Greece Study Group. Hepatocellular carcinoma risk in HBeAg-negative chronic hepatitis B patients with or without cirrhosis treated with entecavir: HepNet. Greece cohort. J Viral Hepat. 2015;22(2):120-7.

6. Kurokawa M, Hiramatsu N, Oze T, Yakushijin T, Miyazaki M, Hosui A, Miyagi T, Yoshida Y, Ishida H, Tatsumi T, Kiso S, Kanto T, Kasahara A, lio S, Doi Y, Yamada A, Oshita M, Kaneko A, Mochizuki K, Hagiwara H, Mita E, Ito T, Inui Y, Katayama K, Yoshihara H, Imai Y, Hayashi E, Hayashi N, Takehara T. Long-term effect of lamivudine treatment on the incidence of hepatocellular carcinoma in patients with hepatitis B virus infection. J Gastroenterol. 2012;47(5):577-85.

7. Hosaka T, Suzuki F, Kobayashi M, Seko Y, Kawamura Y, Sezaki H, Akuta N, Suzuki Y, Saitoh S, Arase Y, Ikeda K, Kobayashi M, Kumada H. Long-term entecavir treatment reduces hepatocellular carcinoma incidence in patients with hepatitis B virus infection. Hepatology. 2013;58(1):98-107.

8. Kobashi H, Miyake Y, Ikeda F, Yasunaka T, Nishino K, Moriya A, Kubota J, Nakamura S, Takaki A, Nouso K, Yamada G, Yamamoto K. Long-term outcome and hepatocellular carcinoma development in chronic hepatitis B or cirrhosis patients after nucleoside analog treatment with entecavir or lamivudine. Hepatol Res. 2011;41(5):405-16.

9. Bruss V. Hepatitis B virus morphogenesis. World J Gastroenterol. 2007;13(1):65-73.

10. Messageot F, Salhi S, Eon P, Rossignol JM. Proteolytic processing of the hepatitis $B$ virus e antigen precursor. Cleavage at two furin consensus sequences. J Biol Chem. 2003;278(2):891-5.

11. Ito K, Kim KH, Lok AS, Tong S. Characterization of genotype-specific carboxyl-terminal cleavage sites of hepatitis B virus e antigen precursor and identification of furin as the candidate enzyme. J Virol. 2009;83(8):3507-17.

12. Duriez $M$, Rossignol JM, Sitterlin D. The hepatitis $B$ virus precore protein is retrotransported from endoplasmic reticulum (ER) to cytosol through the ER-associated degradation pathway. J Biol Chem. 2008;283(47):32352-60.

13. Pang YJ, Tan XJ, Li DM, Zheng ZH, Lei RX, Peng XM. Therapeutic potential of furin inhibitors for the chronic infection of hepatitis $B$ virus. Liver Int. 2013:33(8):1230-8

14. Milich DR, Chen MK, Hughes $J$, Jones JE. The secreted hepatitis B precore antigen can modulate the immune response to the nucleocapsid: a mechanism for persistence. J Immunol. 1998;160(4):2013-21.

15. Chen MT, Billaud JN, Sällberg M, Guidotti LG, Chisari FV, Jones J, Hughes J, Milich DR. A function of the hepatitis B virus precore protein is to regulate the immune response to the core antigen. Proc Natl Acad Sci U S A. 2004;101(41):14913-8

16. Lei RX, Shi H, Peng XM, Zhu YH, Cheng J, Chen GH. Influence of a single nucleotide polymorphism in the P1 promoter of the furin gene on transcription activity and hepatitis B virus infection. Hepatology. 2009;50(3): $763-71$

17. Frelin L, Wahlström T, Tucker AE, Jones J, Hughes J, Lee BO, Billaud JN, Peters C, Whitacre D, Peterson D, Milich DR. A mechanism to explain the selection of the hepatitis e antigen-negative mutant during chronic hepatitis B virus infection. J Virol. 2009:83(3):1379-92.

18. Scaglioni PP, Melegari M, Wands JR. Posttranscriptional regulation of hepatitis $B$ virus replication by the precore protein. J Virol. 1997:71(1):345-53.

19. Kimura T, Ohno N, Terada N, Rokuhara A, Matsumoto A, Yagi S, Tanaka E, Kiyosawa K, Ohno S, Maki N. Hepatitis B virus DNA-negative dane particles lack core protein but contain a 22-kDa precoreprotein without C-terminal arginine-rich domain. J Biol Chem. 2005:280(23):21713-9.

20. Nishikawa SI, Fewell SW, Kato Y, Brodsky JL, Endo T. Molecular chaperones in the yeast endoplasmic reticulum maintain the solubility of proteins for retrotranslocation and degradation. J Cell Biol. 2001;153(5):1061-70.

21. Lee AS. The ER chaperone and signaling regulator GRP78/BiP as a monitor of endoplasmic reticulum stress. Methods. 2005:35(4):373-81.

22. Ma Y, Yu J, Chan HL, Chen YC, Wang H, Chen Y, Chan CY, Go MY, Tsai SN, Ngai SM, To KF, Tong JH, He QY, Sung JJ, Kung HF, Cheng CH, He ML. Glucose-regulated protein 78 is an intracellular antiviral factor against hepatitis B virus. Mol Cell Proteomics. 2009;8(11):2582-94.

23. Awe K, Lambert C, Prange R. Mammalian BiP controls posttranslational ER translocation of the hepatitis $B$ virus large envelope protein. FEBS Lett. 2008;582(21-22):3179-84.

24. Huang KL, Lai YK, Lin CC, Chang JM. Involvement of GRP78 in inhibition of HBV secretion by Boehmeria nivea extract in human HepG2 2.2.15 cells. J Viral Hepat. 2009;16(5):367-75.

25. Li H, Song H, Luo J, Liang J, Zhao S, Su R. Knockdown of glucose-regulated protein 78 decreases the invasion, metalloproteinase expression and ECM degradation in hepatocellular carcinoma cells. J Exp Clin Cancer Res. 2012;31:39.

26. Li Z, Zhang L, Zhao Y, Li H, Xiao H, Fu R, Zhao C, Wu H, Li Z. Cell-surface GRP78 facilitates colorectal cancer cell migration and invasion. Int J Biochem Cell Biol. 2013;45(5):987-94.

27. Zhang XX, Li HD, Zhao S, Zhao L, Song HJ, Wang G, Guo QJ, Luan ZD, Su RJ. The cell surface GRP78 facilitates the invasion of hepatocellular carcinoma cells. Biomed Res Int. 2013:2013:917296.

28. Gu YJ, Li HD, Zhao L, Zhao S, He WB, Rui L, Su C, Zheng HC, Su RJ. GRP78 confers the resistance to 5 -FU by activating the $\mathrm{c}$-Src/LSF/TS axis in hepatocellular carcinoma. Oncotarget. 2015;6(32):33658-74.

29. Zheng $Z H$, Yang HY, Gu L, Peng XM. Proteasomes regulate hepatitis B virus replication by degradation of viral core-related proteins in a two-step manner. Virus Genes. 2016;52(5):597-605. 
30. Yang HY, Zheng NQ, Li DM, Gu L, Peng XM. Entecavir combined with furin inhibitor simultaneously reduces hepatitis $B$ virus replication and e antigen secretion. Virol J. 2014;11:165.

31. Zhao G, An B, Zhou H, Wang H, Xu Y, Xiang X, Dong Z, An F, Yu D, Wang W, Bao $S$, Xie Q. Impairment of the retinoic acid-inducible gene--IFN- $\beta$ signaling pathway in chronic hepatitis B virus infection. Int J Mol Med. 2012;30(6):1498-504.

32. Kunanopparat A, Hirankarn N, Kittigul C, Tangkijvanich P, Kimkong I. Autophagy machinery impaired interferon signalling pathways to benefit hepatitis B virus replication. Asian Pac J Allergy Immunol. 2016;34(1):77-85.

33. Lim SO, Park SG, Yoo JH, Park YM, Kim HJ, Jang KT, Cho JW, Yoo BC, Jung GH, Park CK. Expression of heat shock proteins (HSP27, HSP60, HSP70, HSP90, GRP78, GRP94) in hepatitis B virus-related hepatocellular carcinomas and dysplastic nodules. World J Gastroenterol. 2005;11(14):2072-9.

34. Luk JM, Lam CT, Siu AF, Lam BY, Ng IO, Hu MY, Che CM, Fan ST. Proteomic profiling of hepatocellular carcinoma in Chinese cohort reveals heat-shock proteins (Hsp27, Hsp70, GRP78) up-regulation and their associated prognostic values. Proteomics. 2006;6(3):1049-57.

35. Shuda M, Kondoh N, Imazeki N, Tanaka K, Okada T, Mori K, Hada A, Arai M, Wakatsuki T, Matsubara O, Yamamoto N, Yamamoto M. Activation of the ATF6, XBP1 and grp78 genes in human hepatocellular carcinoma: a possible involvement of the ER stress pathway in hepatocarcinogenesis. J Hepatol. 2003:38(5):605-14.

36. Su R, Li Z, Li H, Song H, Bao C, Wei J, Cheng L. Grp78 promotes the invasion of hepatocellular carcinoma. BMC Cancer. 2010;10:20.

37. Chen WT, Zhu G, Pfaffenbach K, Kanel G, Stiles B, Lee AS. GRP78 as a regulator of liver steatosis and cancer progression mediated by loss of the tumor suppressor PTEN. Oncogene. 2014;33(42):4997-5005.

38. Chiou JF, Tai CJ, Huang MT, Wei PL, Wang YH, An J, Wu CH, Liu TZ, Chang YJ. Glucose-regulated protein 78 is a novel contributor to acquisition of resistance to sorafenib in hepatocellular carcinoma. Ann Surg Oncol. 2010;17(2):603-12.

39. Wu LF, Guo YT, Zhang QH, Xiang MQ, Deng W, Ye YQ, Pu ZJ, Feng JL, Huang GY. Enhanced antitumor effects of adenoviral-mediated siRNA against GRP78 gene on adenosine-induced apoptosis in human hepatoma HepG2 cells. Int J Mol Sci. 2014;15(1):525-44.

40. Chang YJ, Chiu CC, Wu CH, An J, Wu CC, Liu TZ, Wei PL, Huang MT. Glucose-regulated protein 78 (GRP78) silencing enhances cell migration but does not influence cell proliferation in hepatocellular carcinoma. Ann Surg Oncol. 2010;17(6):1703-9.

41. Wei PL, Kuo L, Wang W, Lin FY, Liu HH, How T, Ho YS, Huang MT, Wu CH, Chang YJ. Silencing of glucose-regulated protein 78 (GRP78) enhances cell migration through the upregulation of vimentin in hepatocellular carcinoma cells. Ann Surg Oncol. 2012;19 Suppl 3:S572-9.

42. Biermer M, Puro R, Schneider RJ. Tumor necrosis factor alpha inhibition of hepatitis B virus replication involves disruption of capsid integrity through activation of NF-kappaB. J Virol. 2003;77(7):4033-42.

\section{Submit your next manuscript to BioMed Central and we will help you at every step:}

- We accept pre-submission inquiries

- Our selector tool helps you to find the most relevant journal

- We provide round the clock customer support

- Convenient online submission

- Thorough peer review

- Inclusion in PubMed and all major indexing services

- Maximum visibility for your research

Submit your manuscript at www.biomedcentral.com/submit

CBiomed Central 